\title{
The Process of Making Consumer Purchase Decisions on Halal Cosmetics in Pekalongan City
}

\author{
Nur Kholidah ${ }^{1}$, Muhammad Arifiyanto ${ }^{2}$ \\ \{nur.kholidah92@umpp.ac.id ${ }^{1}$ \} \\ Department of Islamic Economic, University of Muhammadiyah Pekajangan Pekalongan, Indonesia ${ }^{1}$ \\ Department of Management, University of Muhammadiyah Pekajangan Pekalongan, Indonesia ${ }^{2}$
}

\begin{abstract}
The purpose of this study was to determine how the consumer decision making process in purchasing halal cosmetics in Pekalongan City. The method used in this research is descriptive method and chi square test. The number of respondents who became the research object was 150 people with a purposive sampling technique. The purchasing decision making process occurs in five stages. At the introduction stage the most influential thing is product quality, advertising models or brand ambassadors, and the influence of price. In the information search stage, namely the expiration date and the source of commercial information. In the alternative evaluation stage, namely halal guarantee, guarantee of the safety and benefits of cosmetic products labeled halal. At the purchase decision stage is the convenience and practicality of the place of purchase. Post-purchase behavior that influences respondents to make purchases is respondent satisfaction and pricing for cosmetic products. There is one variable that has a relationship between the characteristics of the respondent and the factors of the purchase decision, namely the latest education with cultural factors.
\end{abstract}

Keywords: Cosmetics, Halal label, Purchase decision

\section{Introduction}

The halal lifestyle has recently been sweeping the world, including Indonesia. One of the halal products that are developing in Indonesia is cosmetic products. The reason consumers choose cosmetics with a halal logo is the safety and quality of the cosmetic content. This is as stated by Majid, Sabir, and Ashaf [1] that awareness, religion and halal certificates affect Muslim consumer purchases because they already feel safe with the cosmetic content and quality of the cosmetics to be used.

According to the Association of Indonesian Cosmetics Companies (Perkosmi) in 2016, out of 500 cosmetic companies, only 70 companies are halal certified. With the increasing number of cosmetic companies emerging in Indonesia, the competition in the cosmetics business is getting tougher. To be able to win the competition so as not to be left behind by consumers, producers must follow the factors behind consumer purchasing decisions for a product.

The consumer behavior model can be seen from the decision-making process, where the decision-making process is influenced by external factors and internal factors at the input process stage. Kotler and Keller [2] state that the stages of consumer purchases go through the stage of identifying needs, searching for information, evaluating alternatives, purchasing decisions and post-buying behavior for halal cosmetic products in Pekalongan. This research is expected to provide a clear picture of the decision-making process for purchasing halal cosmetic 
products in Pekalongan. This can also be used as a consideration for determining further marketing strategies for halal cosmetic companies.

Therefore, Several studies on consumer decision making on purchases conducted by Indraswari, et al., [3] Which examined the analysis of factors in purchasing decisions for cosmetics labeled halal in the city of Bogor; Nawawi[4] who examines the analysis of factors that influence consumer decisions in purchasing halal food and beverage products in Jakarta; Ferawati, et al., [5] Who examined consumer decision making on rice purchases in the city of Makassar; Syaiful, et al., [6] Who examined the Purchasing Decision Making Process in Online Stores: The Role of Psychological Factors in Perception of Product Quality and Trust Level.

In addition, several studies regarding the halal label were conducted by Aiedah et al;[7] who researched a descriptive analysis of the generation $\mathrm{Y}$ perceptions on the national halal certification Malaysia; Azreen [8] who examines factors influencing attitude towards halal cosmetic among young adult urban Muslim women: a focus group analysis; Vloreen NM et al., [9] Who examined acceptance on halal food among non-Muslim consumers; Endah [10] who examines the buying behavior of cosmetics labeled halal by Indonesian consumers.

\section{Method}

The type of data used in this study consists of primary data and secondary data. In this study, primary data were obtained from interviews or the results of filling out questionnaires. The questionnaire was structured to identify consumer characteristics and analyze the consumer purchasing decision-making process. Meanwhile, secondary data were obtained from the Central Statistics Agency (BPS), as well as other information related to research obtained from literature books, libraries, and the internet.

The number of respondents who became the object of the study was 150 people with a purposive sampling technique. The consideration in question is that the residents of Pekalongan City are female with a minimum age of 15 years and women who work and use cosmetics every day.

The data analysis used was qualitative and quantitative analysis. Qualitative data processing using descriptive analysis method. Meanwhile, quantitative analysis uses the Chi Square test. The basic Chi Square formula [11] is:

$$
\mathrm{X} 2=\frac{\sum\left(f_{0}-f_{\theta}\right)^{2}}{f_{\theta}}
$$

Information: $X^{2}$ : Chi Square value

$$
\begin{aligned}
& f 0: \text { observed frequency } \\
& f e: \text { expected frequency }
\end{aligned}
$$

The hypothesis in this study are:

$\mathrm{H}_{0}$ : There is no relationship between the characteristics of the respondent and the factors in purchasing decisions for cosmetics labeled halal.

$\mathrm{H}_{1}$ : There is a relationship between the characteristics of the respondents and the decision factors for purchasing cosmetics labeled halal.

Chi Square test was performed using SPSS version 24 with a significant level of 0.05 . The decisions taken from the Chi Square results are:

- If the $\mathrm{p}$ value $<\alpha$, Ho is rejected, it means that the sample data supports a significant 
(significant) relationship.

- If the $\mathrm{p}$ value $\geq \alpha$, Ho is accepted, it means that the sample data does not support a significant relationship (not significant).

\section{Results and Discussion}

\subsection{Respondent characteristics}

Based on the results of the study, it was found that the characteristics of the respondents were based on age, education, occupation, income, expenditure, and frequency of purchases. In this study, the majority of respondents were aged 16 to 25 years with a percentage of $73 \%$. Based on the respondent's latest education, the majority graduated from high school / equivalent with a percentage of 59\%. The majority of respondents work as private employees with a percentage of 58\%. Based on income, the majority of respondents have an income range of $\mathrm{Rp}$ $100,000-\mathrm{Rp} 1,000,000$ with a percentage of $51 \%$. Respondents spent an average of Rp 50,000 - Rp 100,000 per month on buying cosmetics. While the frequency of purchasing cosmetics each year the majority of respondents make 4 to 6 purchases.

\subsection{Identification of the process of decision making to purchase cosmetics labeled halal}

In buying a consumer product through the decision stages. These stages consist of: decision recognition, information search, alternative evaluation, purchase decision, and post-purchase evaluation. Based on the results of the research, the stages of respondents' purchasing decisions for cosmetics labeled halal can be described in the following tables.

\subsubsection{Needs introduction}

The buying process begins when the respondent realizes a problem or need that is triggered by internal or external stimuli. In this study, the process of identifying respondents included purchase motivation, social factors, and halal label considerations when purchasing cosmetics. Based on Table 1, it is known that the motivation or reason for the majority of respondents to buy cosmetic products labeled halal is because of the appropriate quality, which is $63 \%$. The quality of cosmetic products labeled halal is as expected by the respondents, thus encouraging respondents to make purchases.

The most influence with a percentage of $30 \%$ is the advertising model / brand ambassador. For a company, the use of brand ambassadors aims to influence consumers to buy products. $91 \%$ of respondents answered that the halal label was a consideration when buying cosmetic products. Meanwhile, another 9\% stated that they did not consider halal labels on cosmetics before buying. This means that it is important to include the halal label on the packaging of cosmetic products that has been halal certified. 
Table 1. Results of the needs recognition stage

\begin{tabular}{|c|c|c|}
\hline Needs Introduction & Information & Amount (\%) \\
\hline \multirow{5}{*}{ Motivation } & Quality is appropriate & 63 \\
\hline & Price & 13 \\
\hline & Easily obtained & 8 \\
\hline & Promotion push & 5 \\
\hline & Others & 11 \\
\hline$\underline{\text { Sub-Total }}$ & & 100 \\
\hline \multirow{7}{*}{ Social factors } & Advertising model / brand ambassador & 30 \\
\hline & Friend & 25 \\
\hline & Family & 19 \\
\hline & Co-workers & 7 \\
\hline & Seller & 3 \\
\hline & Sales representative & 3 \\
\hline & Others & 13 \\
\hline$\underline{\text { Sub-Total }}$ & & 100 \\
\hline Halal label as & Yes & 91 \\
\hline purchase considerations & Not & 9 \\
\hline Sub-Total & & 100 \\
\hline
\end{tabular}

\subsubsection{Information search}

In this research, information search includes searching for information on halal products, information on packaging and sources of information on cosmetic products with halal labels. The results of the information search process can be seen in Table 2 .

Table 2. Results of the information search stage

\begin{tabular}{lclc}
\hline Information Search & & \multicolumn{1}{c}{ Information } & Amount (\%) \\
\hline Find out information & halal product & Yes & 83 \\
& & Not & 17 \\
& Sub-Total & & 100 \\
\hline Information on & & Expired date & 42 \\
packaging & & Material composition & 38 \\
& & Specification & 13 \\
& & How to use & 7 \\
& Sub-Total & & 100 \\
\hline Resources & & Commercial sources & 60 \\
& & Personal sources & 22 \\
& & Public sources & 11 \\
& & Source of experience & 7 \\
& & & 100 \\
\hline
\end{tabular}

Based on Table 2, it was found that $83 \%$ of respondents sought information on the halalness of cosmetic products before buying. Meanwhile, the other $17 \%$ buy cosmetic products without first looking for halal information. Information on cosmetic product packaging consists of ingredient composition, expiration date, specifications, and usage method. The most important information on cosmetic packaging is the expiration date with a percentage of $42 \%$, because knowing the expiration of make up is important to ensure that the product is still fit for use or not. The source of information where the respondent for the first time knew that most of the 
cosmetics labeled halal were from commercial sources of $60 \%$. Commercial sources include advertisements, salespeople, websites,

Furthermore, respondents mentioned the brand of cosmetic products that first appeared when the word cosmetics was mentioned. Respondents' answers to cosmetic brands by respondents can be seen in Figure 1.

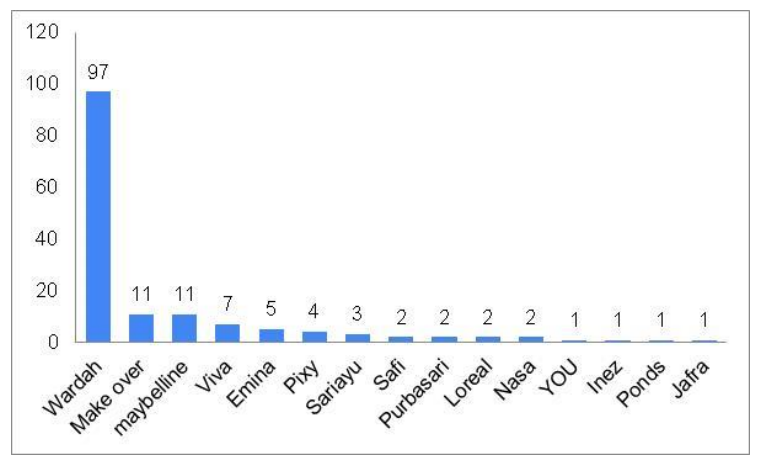

Fig. 1. Response to cosmetic brands

Based on Figure 1, there are several cosmetic brands as responses from respondents about the brands that first come to mind when the word cosmetics is mentioned. The biggest answer is Wardah cosmetic brand with 97, then Make Over with 11, Maybelline with 11. Apart from being asked questions about cosmetic brands, respondents were also asked questions about brands of halal cosmetic products which were their top of mind. Furthermore, the responses of respondents to halal cosmetic brands can be seen in Figure 2.

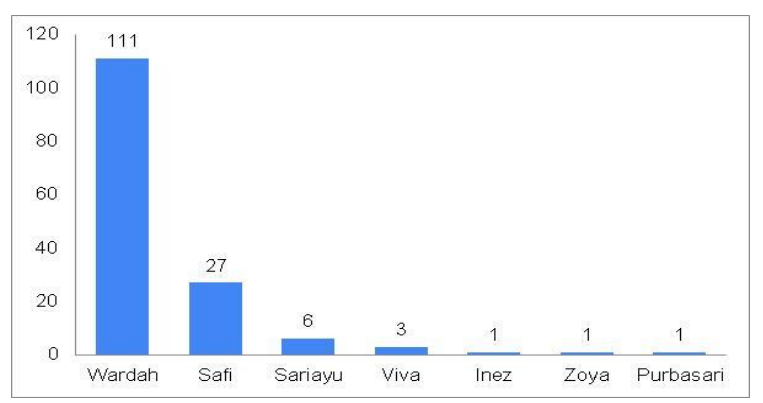

Fig 2. Top of Mind cosmetics labeled halal

Based on the graph in Figure 2, there are three cosmetic brands as respondents' answers about cosmetic brands labeled halal which first came to mind. The biggest answer was Wardah cosmetic brand with 111, Safi brand with 27, and Sariayu brand with 6 .

\subsubsection{Alternative evaluation}

In this study, the alternative evaluation process includes the basic considerations for choosing cosmetics as well as the respondents' confidence in the safety and benefits of the product. Based on Table 3, 65\% of respondents made halal assurance the basis for choosing 
cosmetic products. The basis for considering halal assurance in choosing cosmetics can be caused by the high confidence of respondents in the safety and benefits of cosmetics labeled halal, namely $85 \%$ for safety beliefs and $87 \%$ for confidence in the benefits obtained.

Table 3. Results of the Alternative Evaluation Stage

\begin{tabular}{lll}
\hline Alternative Evaluation & Information & Amount (\%) \\
\hline The basis for the balance of & Halal guarantee & 65 \\
choosing cosmetics & Brand & 14 \\
& Packaging & 1 \\
& Price & 16 \\
& Choice of Variants & 4 \\
& Others & - \\
Sub-Total & & 100 \\
\hline Confidence in the safety of & Yes & 85 \\
cosmetics labeled halal & Not & 15 \\
Sub-Total & & 100 \\
\hline The belief in the benefits of & Yes & 87 \\
cosmetics labeled halal & Not & 13 \\
Sub-Total & & 100 \\
\hline
\end{tabular}

\subsubsection{Buying decision}

In the purchase decision stage, respondents make purchases of the products they think are most needed. In this study, the purchase decision consists of the place of purchase and the reasons for the choice, and the type of purchase made. The results of the purchasing decision process can be seen in Table 4.

Table 4. Results of the Purchasing Decision Stage

\begin{tabular}{lll}
\hline Buying decision & Information & Amount (\%) \\
\hline Where to buy cosmetics & Supermarket & 5 \\
& Convenience store & 7 \\
& Cosmetics specialty shop & 81 \\
& Online shop & 7 \\
Sub-Total & Others & - \\
Reasons for choosing the & Close to where to live & 100 \\
place of purchase & Cheaper prices & 11 \\
& Convenient and practical & 17 \\
& Satisfactory service & 60 \\
Sub-Total & Others & 12 \\
Purchase type & & - \\
Sub-Total & Well planned & 100 \\
\hline
\end{tabular}

Based on Table 4, as many as 81 respondents bought cosmetic products at cosmetic specialty stores. The choice was made because most respondents felt that the place was comfortable and practical. The type of purchase made by the respondent is a planned purchase, the respondent first determines the product of his choice before making a purchase. 


\subsubsection{Post-purchase behavior}

After making a purchase, if the product performance meets expectations, the respondent is satisfied. If the product performance does not meet the criteria, the respondent will be disappointed. These two things will determine whether the respondent should re-purchase or not. In this study, the post-purchase behavior stage includes respondent satisfaction, action when the product runs out, and action if the price goes up. The results of the post-purchase behavior stage can be seen in Table 5.

Table 5. Results of the Post-Purchase Behavior Stage

\begin{tabular}{lll}
\hline Buying decision & Information & Amount (\%) \\
\hline Respondent satisfaction after buying & Satisfied & 97 \\
& Not satisfied & 3 \\
Sub-Total & & 100 \\
\hline The action when the product runs out & Look to other stores & 71 \\
& Buy a similar product & 17 \\
& Don't buy & 12 \\
Sub-Total & & 100 \\
\hline Action if the price of cosmetics goes up & Keep buying & 85 \\
& Buy another product & 13 \\
Sub-Total & Will not buy & 2 \\
& & 100 \\
\hline
\end{tabular}

Based on Table 5, almost all respondents, as many as 97 respondents, were satisfied with the cosmetic products that had been purchased. The respondent's action when the product to be purchased is out of stock as many as 71 respondents will look to other stores and will continue to buy even though the price increases. Both of these can describe the loyalty of respondents to cosmetic products labeled halal which are used quite high. However, even though after the purchase most of them expressed satisfaction, when the price increased, there were some consumers who switched to other similar products by $13 \%$.

\subsection{Results of crosstab analysis with chi-square test}

Based on the results of the Crosstab analysis, it was found that the characteristics of the respondents as a whole did not have a relationship with the factors of the respondent's purchase decision, but there was one variable that had a significant relationship with the Asymp value. Sig (2-sided) Chi-square $<\alpha(0.05)$ namely the last educational variable with cultural factors.

\section{Conclusion}

The conclusions in this study include the characteristics of the respondents are career women who live in Pekalongan City, are young, with the majority of education. graduated from high school/equivalent, working as a private employee, middle class income range, the average expenditure for cosmetics is fifty thousand rupiah to one hundred thousand rupiah per month with a frequency of purchasing cosmetics four to six times per year. The purchasing decision making process occurs in five stages. At the introduction stage the most influential thing is product quality, Advertising models or brand ambassadors, and the influence of price. At the 
information search stage that needs to be considered are the expiration date and the source of commercial information. In the evaluation stage, the alternatives that need to be considered are halal assurance, guarantee of the safety and benefits of cosmetic products labeled halal. The dominant answer at the purchase decision stage is convenience and practicality of the place of purchase. At the post-purchase behavior stage that influences respondents to make purchases is respondent satisfaction and pricing for cosmetic products. The characteristics of the respondents as a whole do not have a relationship with the purchasing decision factors of the respondents, but there is one variable that has a relationship, namely the last education with cultural factors.

\section{Acknowledgement}

On this occasion the compilers offer infinite gratitude to Allah SWT, because with His permission, compilers can complete the research in a timely manner. Compiler also would like to thank profusely to all those who helped in the research. thank you to the grant funding scheme for Beginner Lecturer Research DRPM KEMENRISTEKDIKTI Fiscal Year 2020.

\section{References}

[1] M. B. Majid, I. Sabir, and T. Ashraf, "Consumer Purchase Intention towards Halal Cosmetics \& Personal Care Products in Pakistan,” Glob. Res. Bus. Manag., vol. 1, no. 1, pp. 45-53, 2015.

[2] Kotler dan Keller, Manajemen Pemasaran. Jilid 1. Edisi ke 13. Jakarta: Erlangga.

[3] R. Indraswari, L. Kartika, and S. Septiani, "Analisis Faktor-Faktor Pengambilan Keputusan Pembelian Kosmetik Berlabel Halal di Kota Bogor,” JABE (Journal Appl. Bus. Econ., vol. 5, no. 2, p. 141, 2019, doi: 10.30998/jabe.v5i2.2749.

[4] M. T. Nawawi, "Analisis Faktor-Faktor Yang Mempengaruhi Keputusan Konsumen Dalam Pembelian Produk Makanan Dan Minuman Halal Di Jakarta,” J. Muara Ilmu Ekon. dan Bisnis, vol. 2, no. 1, p. 72, 2018, doi: 10.24912/jmieb.v2i1.1662.

[5] F. Ferawati, S. Saadah, and A. Amrullah, "Pengambilan Keputusan Konsumen Pada Pembelian Beras Di Kota Makassar," J. Sos. Ekon. Pertan., vol. 15, no. 1, p. 1, 2019, doi: 10.20956/jsep.v15i1.5800.

[6] A. V. K. S. Irfan Aulia Syaiful, Khairul Rizal, "Proses Pengambilan Keputusan Pembelian di Toko Daring: Peran Faktor Psikologis Persepsi Kualitas Produk dan Tingkat Kepercayaan," Psikohumaniora J. Penelit. Psikolog, vol. 2, no. 2, pp. 194-208, 2017.

[7] A. Abdul Khalek and R. A. Mohd Mokhtar, "With or Without Halal Logo? A Descriptive Analysis of The Generation Y Perceptions on the National Halal Certification Malaysia," Third Asia Pacific Conf. Adv. Res., no. July 2016, pp. 455-462, 2016.

[8] A. J. bt C. M. Hashim and R. Musa, "Factors Influencing Attitude towards Halal Cosmetic among Young Adult Urban Muslim Women: A Focus Group Analysis," Procedia - Soc. Behav. Sci., vol. 130, no. May, pp. 129-134, 2014, doi: 10.1016/j.sbspro.2014.04.016.

[9] V. N. Mathew, A. M. R. binti A. Abdullah, and S. N. binti M. Ismail, "Acceptance on Halal Food among Non-Muslim Consumers,” Procedia - Soc. Behav. Sci., vol. 121, pp. 262-271, 2014, doi: 10.1016/j.sbspro.2014.01.1127.

[10] N. H. Endah, "Perilaku Pembelian Kosmetik Berlabel Halal oleh Konsumen Indonesia," J. Ekon. dan Pembang., vol. 22, no. 1, pp. 11-25, 2014, [Online]. Available: http://jurnalekonomi.lipi.go.id/index.php/JEP/article/view/31.

[11] Sugiyono, Metode Penelitian Kuantitatif Kualitatif dan R\&D. Bandung: Alfabeta, 2007. 